\title{
Kojot jako kulturní fenomén
}

\author{
Barbora Půtová \\ Katedra teorie kultury (kulturologie) a Ústav pro dějiny umění Filozofické fakultyUniverzity Karlovy v Praze, \\ Celetná 20, 11000 Praha 1
}

\section{LE COYOTE COMME UN PHÉNOMÈNE CULTUREL}

SOMMAIRE Lobjet de cette étude est d’analyser le phénomène du coyote comme un motif mythologique, artistique et littéraire de la culture des tribus indiennes habitant dans la région de l'Amérique du Nord. Une attention particulière est consacrée à la manière dont le coyote est devenu symbole et construction socio-culturelle spécifique qui exprime les valeurs, les normes et les idées essencielles des cultures indiennes étudiées. Une partie de létude interprète limage du coyote dans la société moderne et postmoderne en tant que porteur du caractère scélérat, farceur, créatif et joueur. Lobjectif de létude est de saisir, par une analyse anthropologique et culturologique, la diversité des significations du concepte de coyote dans un contexte historique et culturel concret.

MOTS-CLÉS coyote; anthropologie; mythologie; art; littérature

ABSTRAKT Předmětem studie je analýza fenoménu kojota jako mytologického, výtvarného a literárního motivu kultury indiánských kmenů obývajících oblast Severní Ameriky. Zvláštní pozornost je věnována tomu, jak se kojot stal symbolem a specifickou sociokulturní konstrukcí, vyjadřující podstatné hodnoty, normy a ideje zkoumaných indiánských kultur. Součástí této studie je interpretace obrazu kojota v moderní a postmoderní společnosti jako nositele takových vlastností, jako jsou zlotřilost, šprýmařství, tvořivost a hravost. Cílem studie je uchopit prostřednictvím antropologické a kulturologické analýzy významovou rozmanitost konceptu kojota v konkrétním historickém a kulturním kontextu.

KLÍČOVÁ SLOVA kojot; antropologie; mytologie; umění; literatura

Kojot je psovitá šelma, která se stala mytologickým, náboženským, výtvarným a literárním motivem nativních příběhů severoamerických indiánů. V mýtech indiánských kmenů (např́iklad Karokové, Miwokové, Maiduové, Pomové, Vraní indiáni, Winnebagové, Menominíové, Činukové, Sališové, Nez Percés, Meskalerové a Šusvapové) kojot vystupuje v různých rolích, nejčastěji jako šibal, trickster, kulturní hrdina a stvořitel světa. Skutečná zoologická předloha těchto mýtů kojot, původně obýval severní část Mezoameriky, ale později se rozšíril na území celé Severní Ameriky a Aljašky. Nevyskytuje se pouze na západě Aljašky, v severní Kanadě a na jihovýchodě Ameriky včetně Floridy. Z hlediska zoologické taxonomie je kojot (Canis latrans) blízký šakalovi obecnému (Canis aureus), vlkovi obecnému (Canis lupus) a i psovi domácímu (Canis lupus f. familiaris), nebot’ se jedná o prŕslušníky stejné- ho rodu. Kojot má drobnou a štíhlou stavbu těla. Jeho výška nepřesahuje jeden metr $(58-66 \mathrm{~cm})$ a jeho váha se pohybuje v rozmezí od 10 do 19 kilogramů (obr. 1). Kojota charakterizuje chundelatý ocas a zašpičatělý čenich. Skutečnost, že kojot konzumuje mršiny, napadá zvěř a bez větších problémů se adaptuje na náročné ekologické podmínky, vedla $\mathrm{k}$ tomu, že mu jsou přisuzovány také negativní vlastnosti. V přeneseném významu je např́ílad jako kojot označován prolhaný, nečestný a zavrženíhodný jedinec. Navzdory negativním konotacím, které slovo kojot navozuje, vědci nepochybují o jeho schopnostech přežít. Možná $\mathrm{z}$ tohoto důvodu se $\mathrm{v}$ odborné literatuře setkáváme s následujícími charakteristikami: „(...) má srst velmi hustou a krásnou, jest neobyčejnè chytrý a lstí nahrazuje nedostatek síly tělesné" (Kvapil 2001, 89). Jako synonymum slova kojot slouží výraz americký vlk, lesní vlk nebo 


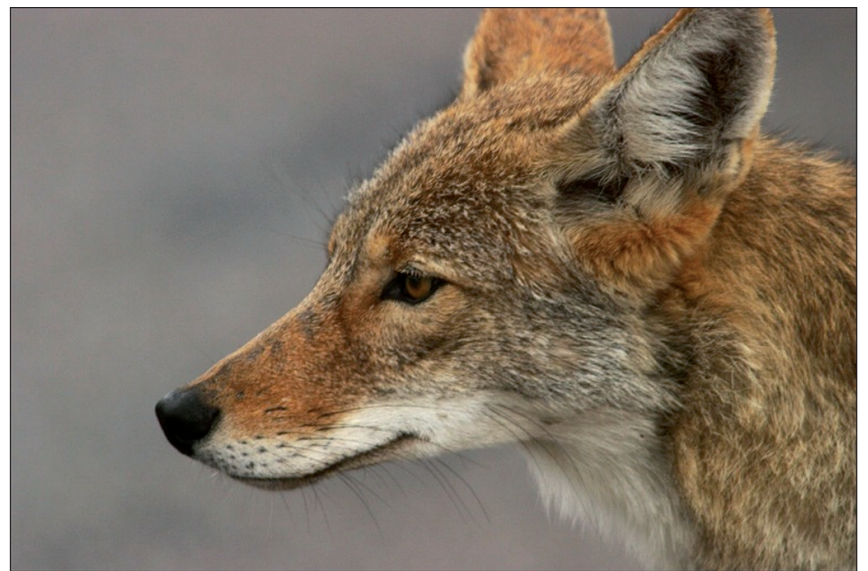

Obr. 1. Zoologická podoba hrdiny této studie - kojot (Canis latrans).

stepní vlk. Kojot je také slangovým výrazem na americkém Jihozápadě, kde představuje osobu placenou za ilegální pašování přes hranice Mexika a Spojených států amerických. V mytologii indiánů amerického Severozápadu kojot představuje unikátní kulturní konstrukt, který symbolizuje bipolární kontrasty lidské osobnosti, zejména principy dobra a zla. $\mathrm{V}$ prŕbězích těchto indiánů zpravidla vystupuje $\mathrm{v}$ roli šibala - amorfní bytosti, jež se transformuje nebo vtělí do jakéhokoli tvora, zvířete a člověka. Šibal konstituuje nový svět, znovu potvrzuje sociální řád, pohybuje se „na prahu“ (liminalita), ztělesňuje proces změny, kreativní mysl i spontaneitu, propojuje svět prrírody, bohů i lidí a stanovuje svébytnou čtvrtou dimenzi prostoru a času. Šibal zosobňuje bytost božskou i zvířecí, jejíž schopnosti zahrnují nadlidské vlastnosti i slabosti, které jsou spojeny s potenciální nerozumností, nevědomostí až hloupostí. Šibal „(...) je predstavitelem a personifikací života, těla či tělesnosti: někoho, kdo nikdy není úplně podmaněn a udolán, kdo je ovládán chtíčem a hladem, kdo neustále běži vstríc bolesti a újmè, kdo je ve svých činech mazaný a hloupý" (Kerényi 2005, 192).

Z transkulturní perspektivy lze šibala srovnávat s antickým Títánem Prométheem, západoafrickým bohem Anansi nebo polynéským polobohem Māui. V mytologických příbězích amerických indiánů kojot využíá svůj důvtip, vynalézavost a hravost. Současně je schopen destruovat svazující pouta žádoucích hodnot a oficiálních norem dané kultury a proměnit se v bezstarostného chlípníka, nenasytu, lidožrouta, zloděje, švindlíře, břídila a šprýmaře. Roli šibala sdílí s havranem, jenž je stejně zlotřilý jako kojot a v rámci své potravní orientace také konzumuje mršiny. Francouzský sociální antropolog a etnolog Claude Lévi-Strauss (1908-2009) dokonce kojota a havrana označil za usmiřující protipóly a zprostředkovatele mezi životem a smrtí. Kojota považuje Lévi-Strauss za mrchožrouta, který se na straně jedné nachází mezi masožravci a býložravci a na straně druhé mezi zemědělstvím a válkou.

$\mathrm{V}$ mytologii severoamerických indiánů kojot stvořil svět, zvírata a lidi nebo obstaral oheň. Podle mýtů indiánů kmene Miwok si kojot po stvoření světa svolal všechna zvírata. Jeho úmyslem bylo stvořit lidi a poradit se o jejich podobě. Každé ze zvírat do „obrazu člověka“ projektovalo své vlastní

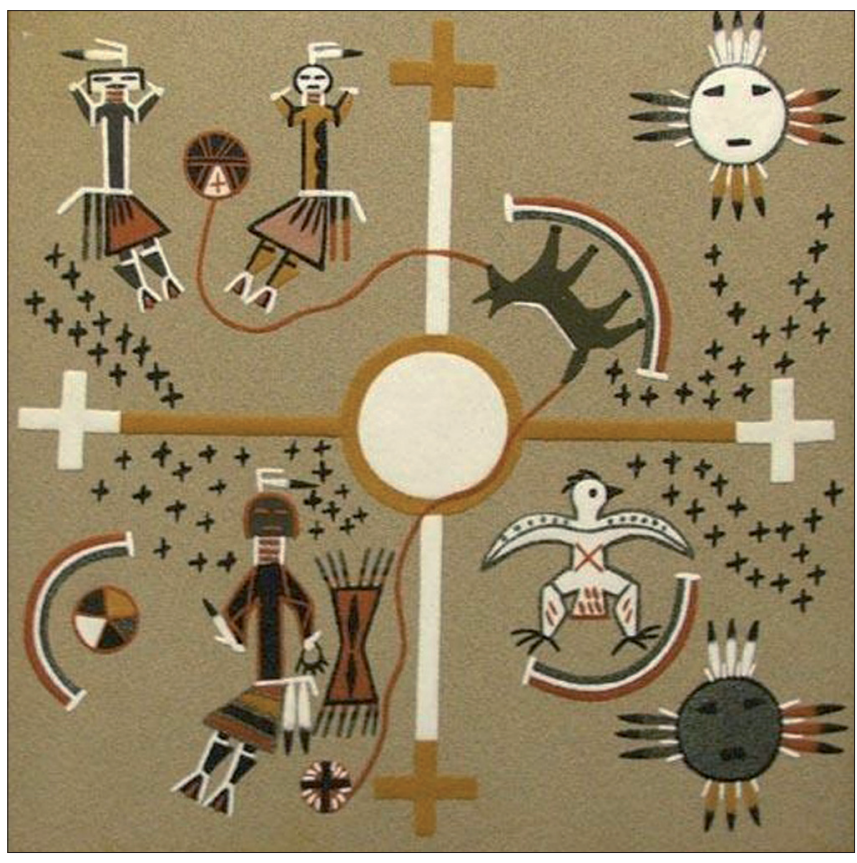

Obr. 2. Kojot jako dárce ohně, písková malba indiánského kmene Navahů.

tělesné charakteristiky. Nakonec ovšem zvítězil kojotův egoismus. Kojot bez ohledu na přání ostatních zvírat stvořil lidi k obrazu svému - chytré a důvtipné. V mýtech Šelanů jsou zvírata a svět dílem Stvořitele, který se rozhodl stvořit lidi. Ovšem některá zvířata, k nimž patřil i kojot, nebyla spokojena se svým jménem. Jednalo se o první vzepření vưli a zákonu Stvořitele, jenž ustanovil vůdcem, udržovatelem míru a dohlížitelem nad ostatními zvířaty kojota. Kojot se totiž řídil jeho př́kazem pouze do chvíle, kdy formuloval svůj vlastní zákon. Stvořitel za tuto vzpouru kojota potrestal tím, že jej vyhostil na odlehlý ostrov. V důsledku se vůdci zvírat stali vlci. $\mathrm{S}$ motivem trestu, tentokrát $\mathrm{v}$ kontextu lidského stárnutí, se můžeme setkat také v mýtech Maidů. Podle těchto indiánů je kojot prrímo zodpovědný za přítomnost smrti v lidském životě. Mýty Maidů vypráví příběh, v němž se lidé, pokud začali pocitovat, že stárnou, ponořili do jezírka a po vynoření znovu omládli. Kojot však lidské bytosti ponoukal k poznání smrti. Za nerozvážnost byl potrestán smrtí vlastního syna. Ačkoliv žádal Stvořitele o navrácení jeho života, Stvořitel se nenechal přesvědčit: „Ted’ už je pozdě, ted' už je přiliš pozdě“ (Snyder 1995, 49). Poselství této tematické vrstvy mýtů o kojotovi je více než nadčasové, nebot za každý tvůrčí čin, vzpouru proti sociálnímu řádu a konformitě i touhu po poznání musí rebelové zaplatit.

Zcela odlišnou dimenzi rozporuplné osobnosti kojota prezentují mýty o jeho zásluze na získání ohně. V příbězích severoamerických indiánů sehrál kojot stejnou roli jako řecký Prométheus, nebot' umožnil lidem překročit hranici mezi světem přírody a kultury. Např́klad jeden z mýtů Meskalerů vypráví, že původně byl oheň lidem nedostupný, nebot jej uchovávalo uvnitř střeženého kruhu hejno much. Statečný kojot do tohoto kruhu prostrčil ocas, který vzplanul a rozšířil plameny ohně i za hranicemi kruhu. Jinou verzi př́iběhu 


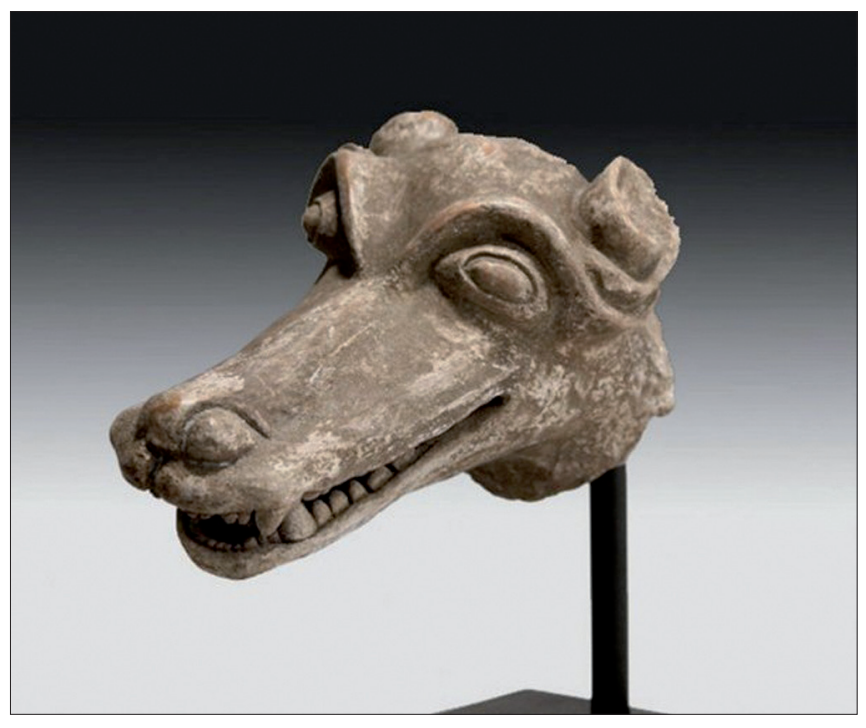

Obr. 3. Keramická hlava kojota (kolem 1350-1500), indiánský kmen Aztéků.

o kojotovi jako o bájném světlonošovi obsahují mýty indiánů kmene Navahů, podle nichž kojot ukradl oheň Slunci a daroval jej lidem (obr. 2).

Významnou osobnostní charakteristikou kojota, s níž se často setkáváme v mýtech amerických indiánů, byla jeho touha po zakázaném sexu. Kojotovo pokušení a vášeň po intimním spojení s tabuizovanými ženami bylo tak velké, že předstíral i cizí identitu. Naprŕklad na sebe dokázal vzít podobu svého bratra, vnuka nebo švagra, aby mohl souložit s jejich manželkami. Sexuální dobrodružství kojot vyhledával s cizími mladými dívkami i blízkými př́buznými. O jeho incestních sklonech svědčí např́iklad mýty Sanpoilů, ve kterých se oženil s vlastní dcerou. Mýty Pimů zase ilustrují kojotovu schopnost využít pro dosažení sexuálního uspokojení lest. Například $\mathrm{v}$ jednom z mytologických př́běhů kojot předstíral zranění a požádal švagrovou, aby ho přenesla na zádech. Tak se ocitl ve výhodné fyzické poloze, kterou okamžitě využil k tomu, aby dosáhl snadného pohlavního spojení. Kalapujové ve svých mýtech zaznamenali příběh, $\mathrm{v}$ němž kojot neváhal svést manželku svého bratra Pumy. Po odhalení smilstva vytáhl bratr Puma $\mathrm{z}$ břicha své manželky dvě děti - vlastní a bratrovo. Své nechal odnést krahujcem do nebe a kojotovo vhodil do řeky. V další roli kojot čelí nebo podléhá nástrahám, stává se předmětem lsti a výsměchu nebo vlastní pýchy, chtivosti a chtíče. V mýtech Klikitatů je např́klad zaznamenána kojotova sexuálně motivovaná záliba uléhat vedle vlastních snach. Kojot vždy rozdělal oheň, $z$ něhož vylétaly jiskry. Snachy si ve strachu vyhrnuly šaty a odhalily své vnady, což bylo kojotovi zdrojem potěšení. Jinou variantu kojotovi sexuální lstivosti zaznamenaly mýty Vraních indiánů. Podle jednoho z příběhů se kojot ukryl v jahodách a nechal vystupovat pouze špičku svého penisu. Jedno z mladých děvčat, jež přišlo sbírat lesní plody, odlišnost a nevšednost této podivné jahody, kterou se neúspěšně pokoušela vytrhnout ze země, komentovalo následujícími slovy: „Je úplně jiná než ty ostatní (...) Tahle má asi moc silné kořeny, myslela si“ (Topol 2008, 104). Výpravu

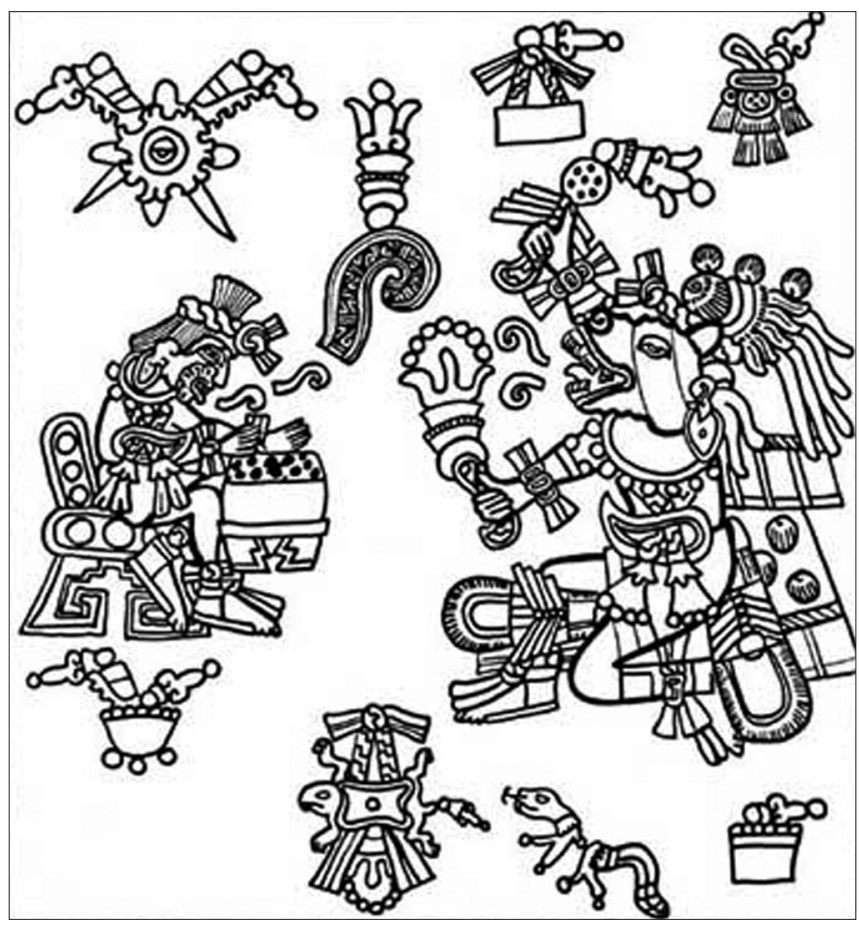

Obr. 4. Aztécký bůh hudby, tance a zpěvu Huehuecoyotl v podobě kojota, rukopis Codex Borbonicus (Kodex bourbonský, 1507).

za krásnými dívkami kojot podnikal také v mýtech Ponků. Podle jednoho z př́běhů, hnán svojí touhou po krásných ženách, navštívil dokonce čarodějnici a její dvě dcery. Tyto ženy měly velmi špatnou pověst, nebot’ se nikdo $\mathrm{z}$ jejich návštěvy nevrátil živý. Kojot ovšem úskalí spojená s návštěvou úspěšně překonal. V noci mu totiž nevlastní dcera, zajatkyně čarodějnice, vyzradila léčku, kterou pro něj čarodějnice připravila. Nebezpečí číhalo ve vagíně dívek, jež byla plná zubů. Kojot neváhal a zabil starou čarodějnici i její vlastní dceru. Ráno si odvedl mladou dívku a odstranil jí nebezpečné zuby z vagíny - „(...) až na jeden zoubek, z kterého měli při milování spoustu rozkoše" (Topol 2008, 100).

Jinou variantu kojotových výprav za přitažlivými ženami obsahují mýty o kojotových námluvách, jejichž cílem bylo nejenom sexuální potěšení, ale i získání legitimní nevěsty. Například v prŕběhu Wasků si vzal na sebe kojot podobu mladého muže a ucházel se o ruku krásné a mladé náčelníkovy dcery, jejíž manžel se měl jednou stát nastupujícím náčelníkem. Dosavadní náčelník nevyžadoval žádné statky, nýbrž štěstí své dcery. Kojot usiloval získat dívčino srdce a na její přání vytvořil jezírko, v němž se mohla v soukromí koupat. Dívčino štěstí vedlo k uzavření sňatku. Ovšem na vrcholcích hor usedaly dvě staré babičky, které sledovaly dívku během koupání. Smály se a rozhlásily její tajemství. Neštastná dívka se ponořila do Velké řeky. Kojot ji ovšem stihl dohonit na kanoi. Z obou se u velké vody, kde zapadá Slunce na noc, staly letní kačenky. S motivem námluv se můžeme setkat také u indiánů Sahaptinů, vyprávějících mytologický př́iběh kojota, jenž se jako nosič zvěřiny ucházel o nevěstu. Jednalo se o ženu, která se chtěla provdat za vysoce postaveného muže. Kojot jí nejdříve nabídl svého staršího bratra Orla, jehož obživou byl 


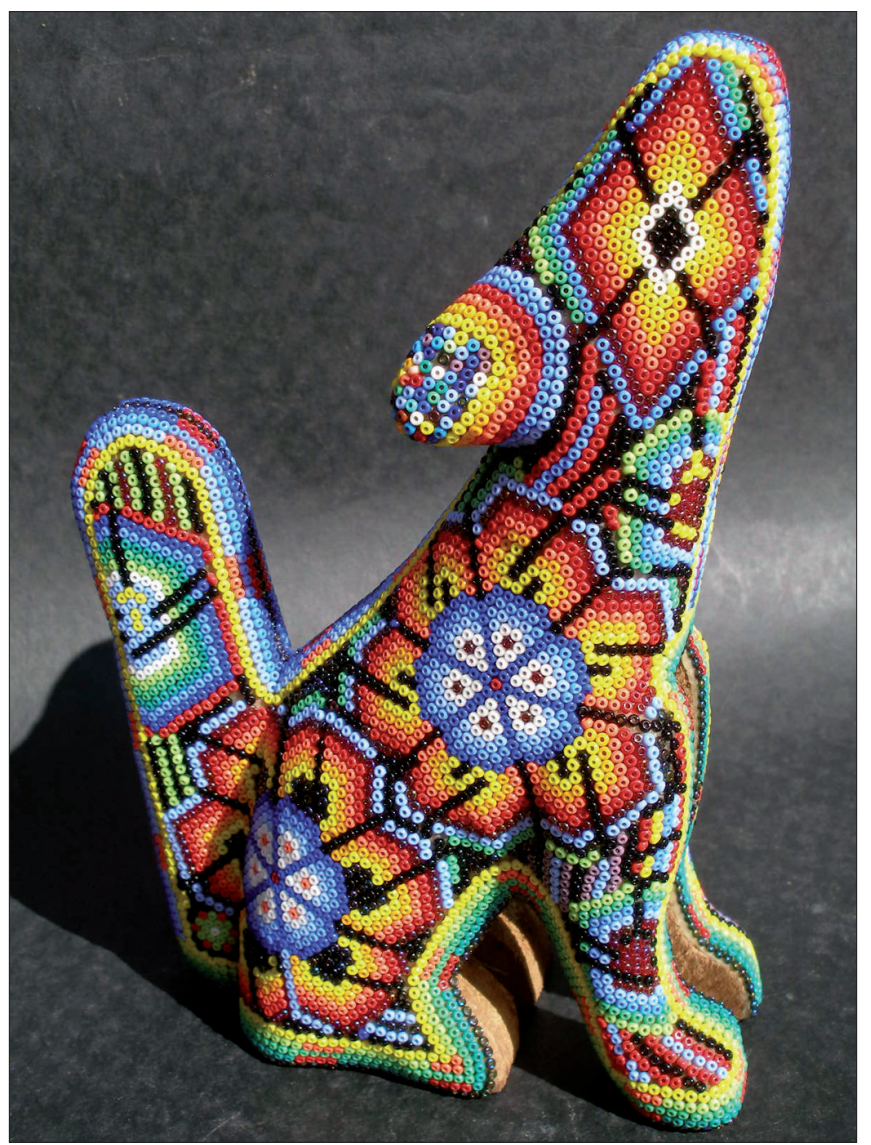

Obr. 5. Dřevená skulptura kojota zdobená barevnými skleněnými korálky, indiánský kmen Huičolů.

lov. Orel ovšem ženu odmítl, a proto se ji kojot rozhodl získat za manželku sám pro sebe. Žena se ale raději proměnila v lososa. Odmítnutý a dotčený kojot prohlásil, že žádná žena se již sama nebude snažit provdat za vysoce postaveného muže. Výhradně muži budou hledat a dvořit se potenciálním manželkám. „Už nikdy se sama žena neptá urozeného, zda si ji chce vzít za ženu" (Lévi-Strauss 2009, 258). Zamyslíme-li se nad tímto poselstvím z hlediska významu, který hrála exogamní výměna žen v preliterárních společnostech jako nástroj uzavírání přátelských koalicí mezi muži, je evidentní, že př́iběhy o kojotových námluvách odrážejí asymetrické postavení žen v preliterárních společnostech. Navzdory ženské přitažlivosti a potenciální lásce, jíž dokáží ženy vzbudit, jsou to nakonec muži, kteři rozhodují o ženském osudu.

Další mytologickou podobou kojota je jeho obraz bojovníka, kanibala nebo lovce. S kojotem potírajícím zlo se např́klad můžeme setkat v mýtech Sališů, kde zabíjí příšery. Naopak jako nositel zla je interpretován v mýtech indiánů Čirikava, nebot zde požírá lidi. V mytologii severoamerických indiánů existuje dokonce př́běh o kojotovi, který obelstil výra, aby mohl zabíjet a pojídat lidi v nejvyšším místě horského sedla. Předmětem kojotovy dravé apetence nebyli pouze lidi, nýbrž také lososi. V průběhu jejich lovu kojot neváhal využít své lstivosti a podvést i orgány svého vlastního těla. Pikantní př́iběh obsahuje mytologie Sališů. Kojot zde použil k lovu ryb své

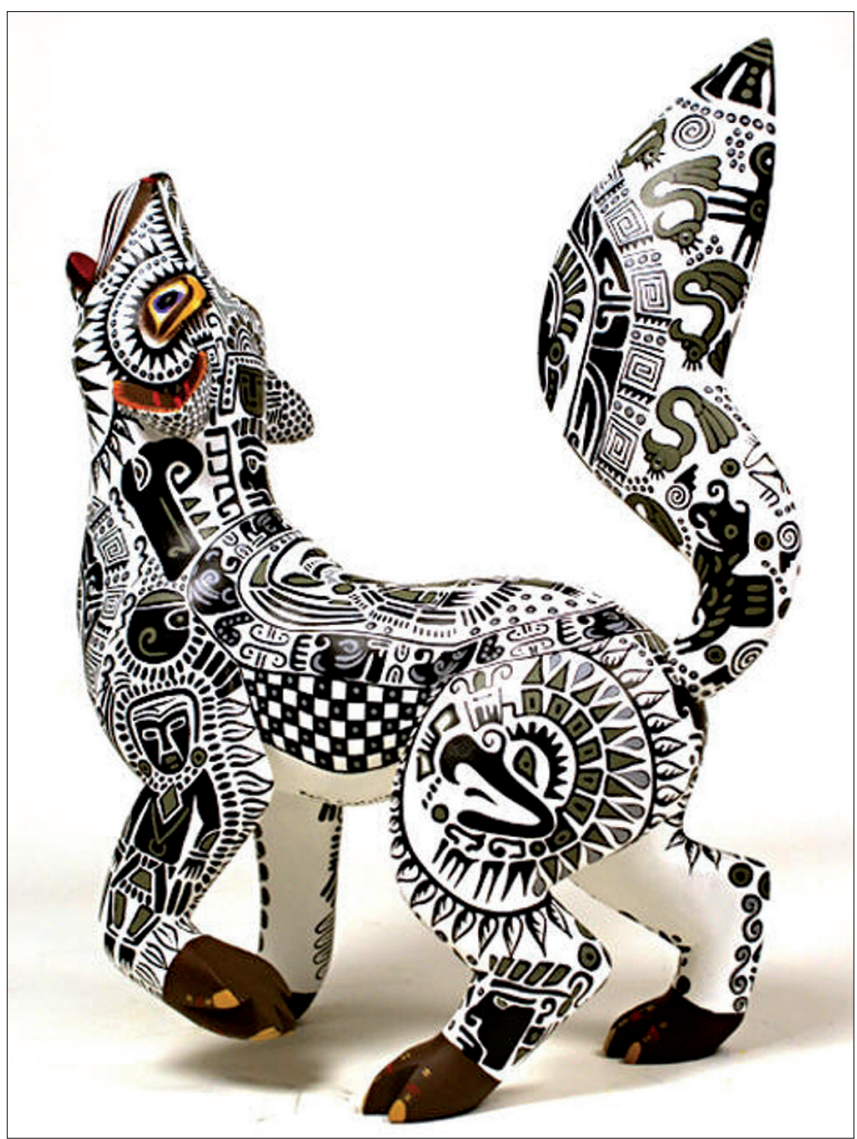

Obr. 6. Dřevěná malovaná řezba Kojot, mexický umělec Mario Castellanos.

vlastní hýždě, jež za tímto účelem vyňal ze svého těla. O úlovek se ovšem nerozdělil a snědl jej sám. Jeho oklamané pozadí nad touto zradou znechuceně svraštilo rty. Proto se i lidské hýždě odlišují od úst, ačkoliv původně vypadaly stejně. V mýtech indiánů Šestů si kojot zarybařil se samotnými indiány. Během návratu domů si chtěl odpočinout, usnul a roje žlutých kazajek (sršni) mu ulovené lososy ukradli. Vrátil se proto zpět k indiánům, s nimiž nachytal nové lososy. Během návratu se ale událost opakovala. Šestové se rozhodli kazajky zahnat a darovali kojotovi třetí ranec lososů. Kazajky i tentokrát úlovek uloupily a vletěly s lososím masem do hory Shasta. Indiáni se rozhodli kazajky vykouřit, k čemuž jim pomohla želva, která svým krunýřem zakryla otvor na vrcholu hory. Hora explodovala a $\mathrm{z}$ díry vyletěli uvaření a vyuzení lososi. $\mathrm{V}$ této souvislosti lze konstatovat, že spojenectví kojota s lidmi umožnilo vítězství kultury nad prŕrodou v intencích Lévi-Straussova dichotomického vztahu a přechodu od syrového k vařenému.

Jednou z klíčových kategorií fungování jednoduchých preliterárních společností byla vzájemně výhodná reciproční výměna. Také kojot $\mathrm{v}$ mýtech, které si o něm lidé vyprávěli, rád směňuje. $\mathrm{V}$ jeho př́padě ovšem výměnné transakce nabývají absurdní podoby. Naprríklad v jednom z příběhů vyměnil svůj vlastní pohlavní úd za penis, jímž dokázal porazit strom jako sekera. Bohužel penis neměl k dispozici stromy, které by mohl kácet, a proto obrátil svou sílu proti kojotovi. Kojot si dokonce 
vyměnil své oči se žonglérem. Poté co je vyhazoval do vzduchu, je odnesl sup v zobáku. Kojot si ihned vyrobil náhradní oči z květin. Ty ovšem zvadly a kojot oslepl. Kojot neváhal a slepé oči ihned vyměnil s hlemýžděm, který tak navždy ztratil svůj zrak. Příběhy o kojotových výměnách v sobě skrývají nadčasové poselství. V preliterárních společnostech, stejně jako v období postmoderny, je unáhlené a krátkozraké sázet při svých směnách na okamžitý prospěch a zisk. Z dlouhodobé perspektivy nás totiž př́roda za naši touhu po exponenciálním růstu a bezohledném uspokojování potřeb nekompromisně potrestá.

Mytologické systémy severoamerických indiánů nezanikly společně s nativními kulturami, které je vytvořily. Mýty amerických indiánů se staly součástí kulturního dědictví lidstva a ve 20. století inspiračním zdrojem literární a výtvarné umělecké tvorby autorů, jejichž původ je svázán s autochtonními obyvateli Severní Ameriky. Např́klad kanadský dramatik a básník indiánského původu (Delawarové) Daniel David Moses (narozen 1952) v divadelní hře Coyote City (Město kojotů, 1990) aktualizuje motiv práva a touhy indiánů na vlastnictví půdy, v níž by byla pochována jejich těla. Johnny telefonuje šest měsíců po vlastní smrti přítelkyni Leně, nebở jeho duch nemůže odejít v pokoji do říše mrtvých. Ve hře je uvedena analogie Johnnyho osudu s legendou kmene Nez Percés o kojotovi a jeho mrtvé ženě. Kojot po smrti své ženy trpí a vypraví se do říše mrtvých s prosbou o její navrácení. Jeho přání bude vyslyšeno za podmínky, že se jí v průběhu návratu domů nedotkne. Toto pravidlo kojot nedodrží, a proto ji navždy ztrácí: „Duchové se nevrací $k$ těm, kdo neumí držet slovo. Nakonec zůstal sedèt sám na tý veliký pustý pláni, pod žhnoucím sluncem, a predstíral, že jí bobule a pozoruje stáda koní. Pokoušel se vrátit tu sladkou chut’ v ústech, na kterou se pamatoval" (Moses 2007, 214).

Motiv kojota jako šibala $\mathrm{v}$ románech a povídkách uplatňuje také kanadský spisovatel indiánského (Čerokíové) a řeckého původu Thomas King (narozen 1943). Americký spisovatel Michael Chabon (narozen 1963) představil v knize Summerland (Letní země, 2002) alegorii světa jako velkého stromu, jehož větve symbolizují jednotlivé světy. Nikdo nemůže vstoupit ani odejít z teritoria Zářící země, analogické duchovní říši indiánů, jejímž autoritativním vládcem je kojot.

Míra flexibility a nezdolnosti kojotího organismu inspirovala v postmoderní společnosti k jeho ztotožnění s kyborgem - živou bytostí, která syntetizuje tělo a stroj a je obohacena o mechanické nebo elektronické systémy. Kyborg představuje osvobozenější „lidskou“ bytost a je nositelem dokonalé existence. Přiblížit se kyborgu skrývá příslib úniku z reálného světa a právo na život, jehož struktury si určuje jednotlivec v závislosti na svobodné volbě. Volba se může také proměnit v odtělesnění a mizení těla, které poskytuje plné odevzdání se kyberprostoru, relativizujícímu veškeré mentální i tělesné limity. V roli kyborga ztvárnil kojota například americký autor science fiction L. Neil Smith (El Neil, narozen 1946) v románu The Nagasaki Vector (1983) nebo americká autorka science fiction a fantasy Kage Bakerová (1952-2010) v knize Sky Coyote (Nebeský kojot, 1999).

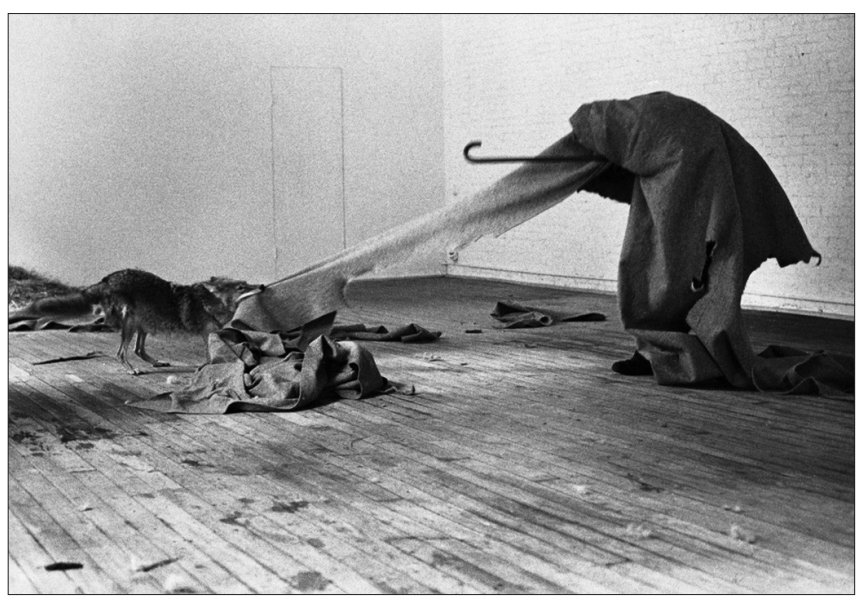

Obr. 7. Fotografie kojota a německého sochaře a malíře Josepha Heinricha Beuyse (1921-1986) z performance Coyote: I Like America and America Likes Me (Kojot: Mám rád Ameriku a Amerika má ráda mne, 1974).

Motivy transformace, převtělení a pestré variability indiánské mytologie vložil americký spisovatel Christopher Moore (narozen 1957) do svého románu Coyote Blue (1994, Modrý kojot, česky: Kojotí stesk). Do vzájemné opozice postavil kojota jako žertující božstvo a amerického muže, ztělesňujícího dokonalé sebeovládání a disciplínu. Kojot se stane ochranným duchem inteligentního a racionálního podnikatele Sama Huntera. Disponuje schopností libovolně přijímat zvírecí nebo lidskou podobu (indiána) a převrací přirozený řád věcí. $\mathrm{V}$ rámci svého nepředvídatelného chování například svedl i Samovu nepohlednou sekretářku. Sam je ovšem přistihl a indiána ve zlosti napadl. Indián upadl na zem, předstíral smrt a následně se jeho tělo začalo měnit: „Samovy oči se rozšírily hrůzou, když viděl, jak se ty nohy a ruce zkracují a obrůstají srstí, jak se tvár úží do vousaté tlamy a páteř protahuje do huňatého ocasu. Než mohl Sam popadnout dech, díval se na tělo velkého černého kojota" (Moore 1998, 85).

Polarita odlišných složek osobnosti kojota inspirovala i literáty v evropském kulturním okruhu. Švýcarský spisovatel německého původu Hermann Hesse (1877-1962) v knize Der Steppenwolf (Stepní vlk, 1927) prostřednictvím postavy intelektuála Harryho Hallera odsoudil konformní buržoazii a lidskou všednost. Harrym zmítají dva nesourodé subjekty člověk a stepní vlk, kterého ho dovádějí k depresím, sebevražedným myšlenkám a smyslnosti anebo podlehnutí alkoholu i drogám. Stepní vlk „(...) se cítil jako naprosto zvláštní jedinec, jako podivín a chorobný samotár̆, brzy zase jako mimoŕádné individuum, nadané geniálními vlastnostmi a povznesené nad nízké normy životního průměru" (Hesse 2006, 59). Neochočená a nebezpečná povaha stepního vlka ústí v rozpolcenost a ambivalentnost života Harryho Hallera, jehož kumulativním bodem se stává vražda.

Ve výtvarném umění je kojot doložen $v$ aztécké kultuře, jež kojota považovala za symbol války a prohnanosti (obr. 3). $\mathrm{V}$ podobě kojota byl ztvárňován aztécký bůh hudby, tance a zpěvu Huehuecoyotl. Tančící kojot s lidskými končetinami se nachází v aztéckém rukopise Codex Borbonicus (Kodex 


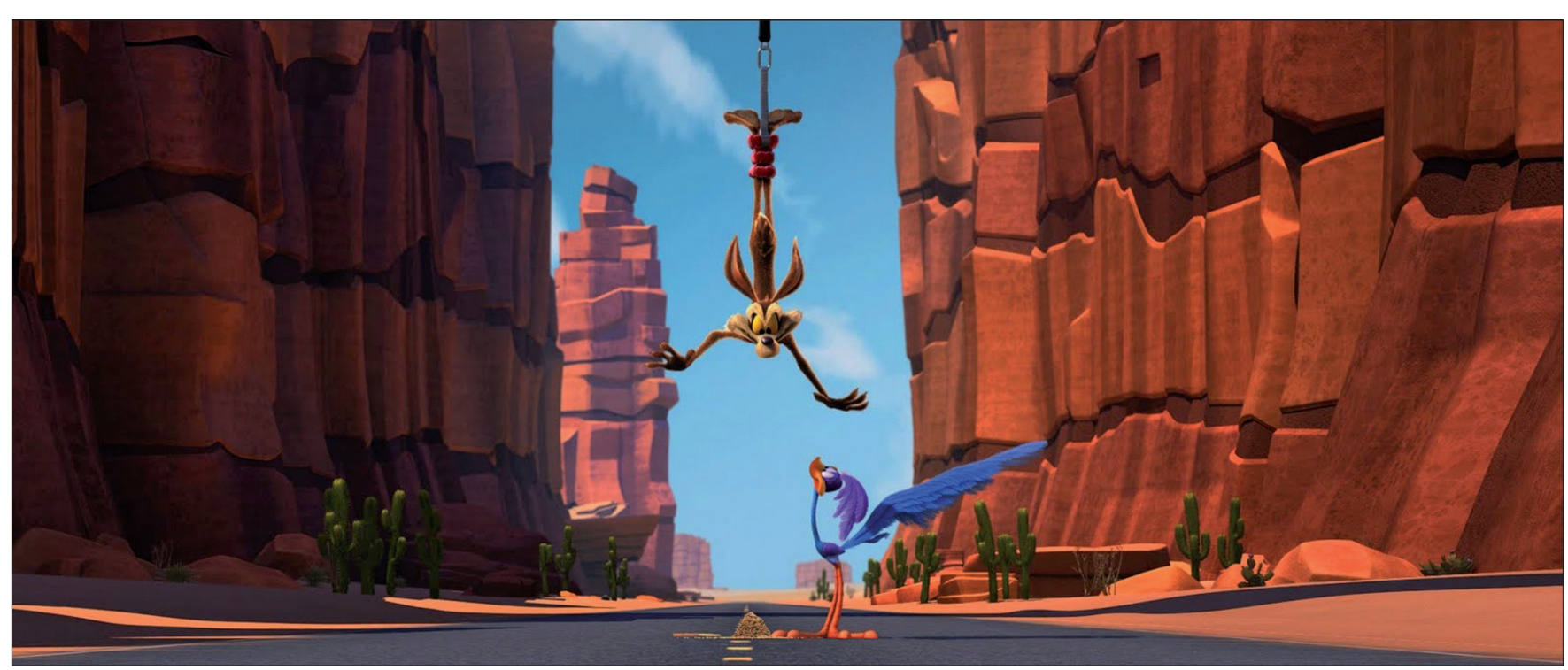

Obr. 8. Kojot a kukačka v americkém animovaném seriálu Will E. Coyote and Road runner (Pták uličník a kojot Wilda).

bourbonský, 1507) (obr. 4). Do kojota se proměňoval i zrádný, všudypř́tomný a vševědoucí aztécký bůh války a noci Tezcatlipoka, jenž byl v mnoha aztéckých mýtech hlavním protihráčem boha věd a umění Quetzalcoatla. Kojot symbolizoval jeho chtonický aspekt. Indiáni kmene Huičolů z pohoří Sierra Madre až do současnosti užívají motiv kojota při tvorbě uměleckých artefaktů, např́iklad dřevených skulptur nebo masek, které zdobí skleněné korálky (obr. 5). ${ }^{1}$ Pop-artovou estetiku v kombinaci se zápotéckými motivy uplatnil mexický umělec Mario Castellanos v dřevěné skulptuře Kojot (obr. 6). Postmoderní rukopis vtiskla kanadská umělkyně Joy Austin Kirkwood multimediálnímu objektu Kojot (2003).

Nástrojem nepředvídatelných událostí se stal kojot v performanci Coyote: I Like America and America Likes Me (Kojot: Mám rád Ameriku a Amerika má ráda mne, 1974), jíž realizoval německý sochař a malíř Joseph Heinrich Beuys (19211986). Tři dny strávil s kojotem v prázdné místnosti v newyorské galerii René Blocka. Průběh performance dokumentují fotografie, na nichž je Beuys zpravidla překrytý a zavinutý v plsti jako pastýř s holí (obr. 7). Kojota sledoval, předčítal mu poezii nebo se snažil napodobit jeho chování. Projevy kojotovy obezřetnosti a agresivity ústily v jeho ponížení jako symbolu destrukce bílého muže amerického kontinentu a autochtonního indiánského obyvatelstva. Dialog Beuyse a kojota odkazoval na šamana, který měl úzký vztah se zvířaty, rozuměl jejich řeči a proměňoval se do jejich podoby. $\mathrm{V}$ této souvislosti lze zmínit, že kojotí kůže může být součástí oděvní výbavy šamanů. Ve vydělané kůži kojota chodili i skalpovaní muži, kteří přežili tento krutý zvyk, rozšśřený mezi severoamerickými indiány.

Kojot vstoupil i do světa postmoderního animovaného seriálu. Americký animátor Chuck Jones (1912-2002) je auto-

1 Před příchodem evropských misionářu tyto artefakty pokrývaly částečky mušlí, kamínky a semena (Muller 1978). rem postav amerického animovaného seriálu Will E. Coyote and Road runner (Pták uličník a kojot Wilda, od roku 1949), $\mathrm{v}$ němž se zarputilý kojot snaží dostihnout hbitého a rychlého ptáka (obr. 8). Tato kukačka², utíkající po pouštních silnících za vydávání zvuku mig-mig, vždy přelstí kojota, jenž se v mnoha epizodách zpravidla stává obětí své vlastní nástrahy. Kojot vystoupil i v americkém seriálu The Simpsons (Simpsonovi, od roku 1987), jejž vytvořil americký karikaturista a scénárista Matthew Abram Groening (narozen 1954). V díle El Viaje Misterioso de Nuestro Jomer (Homerova mystická cesta, 9. díl, 8. řada, 1997) se Homer po požití chilli papriček dostává v halucinacích na cestu za poznáním. Na pyramidě se setkává s mystickým kojotem, jenž se stane jeho duchovním rádcem. Kojot vybízí Homera, aby dosáhl klidné mysli. V průběhu jejich konverzace se ovšem náhle zakousne do Homerovy nohavice. Poté co je Homerem zahnán, omlouvá se slovy: „Sorry, I am a coyote" (Odpust', jsem kojot).

Čím vším tedy může být kojot? Jaké je jeho transkulturní poselství přesahující hranice mytologie, vědy, krásné literatury, televizních seriálů i výtvarného umění? Rozmanité variace na téma kojot je možné interpretovat jako univerzální zprávu o mnohorozměrnosti lidské přirozenosti - sémiotický text, který vypráví nekončící příběh o tom, že člověk je současně zlý i dobrý, racionální i iracionální, moudrý i pošetilý, egoistický i altruistický. Jedním slovem „vypečený“ šibal. Stejně jako Vy i Já.

2 Road runner je ve skutečnosti americký název pro kukačku kohoutí (Geococcyx californianus), což je velká pozemní kukačka (51-61 cm), která při útěku nebo lovu ještěrek, hadů, ptáků a bezobratlých živočichů, dokáže běžet rychlostí $24-32 \mathrm{~km} / \mathrm{h}$. 


\section{LITERATURA}

Anděra, Miloš (1999): České názvy živočichů II. Savci (Mammalia). Praha: Národní muzeum.

Clark, Ella E. - Edmonds, Margot, eds. (1989): Voices of the Winds: Native American Legends. New York: Facts on File.

Clarková, Ella E. - Edmondsová, Margot, eds. (2000): Hlasy větrů: Mýty severoamerických Indiánů. Praha: Nakladatelství Lidové noviny.

DeMallie, Raymond J., ed. (2001): Handbook of North American Indians XIII.: Plains. Washington, D. C: Smithsonian Institution Press.

Dobie, Frank (1961): The Voice of the Coyote. Lincoln: University of Nebraska Press.

Eliade, Mircea (1987): The Encyclopedia of Religion. Collier Macmillian: New York.

Erdoes, Richard - Ortiz, Alfonso, eds. (1984): American Indian Myths and Legends. New York: Panthon Books.

Hesse, Hermann (2006): Stepní vlk. Praha: Argo.

Hynes, William J. (1993): Mapping the Characteristics of Mythic Tricksters: A Heuristic Guide. In: Hynes, William J. - Doty, William G., eds., Mythical Trickster Figures: Contours, Contexts and Criticisms. Tuscaloosa: The University of Alabama Press, 34-42.

Jordan, Michael (1997): Encyklopedie bohů. Praha: Volvox Globator.

Kašpar, Oldřich (2006): Kojot a oposum a jiné mexické pohádky / El coyote y el tlacuache y otros cuentos. Praha: Garamond.

Kelemen, Jozef (2001): Kybergolem: Eseje o cestě Adama ke Kyborgovi. Olomouc: Votobia.

Kerényi, Karl (2005): Šibal ve vztahu k řecké mytologii. In: Radin, Paul - Kerényi, Karl - Jung, Carl Gustav, Trickster: Mýtus o Šibalovi. Indiánský mýtus v kontextu světových mytologií. Praha: Dobra, 180-198.

Konitzky, Gustav A. (2008): Pohádky, legendy a bajky severoamerických Indiánů. Brno: Computer Press.

Kř́ížvá, Markéta (2005): Aztékové: Pưvab a krutost indiánské civilizace. Praha: Aleš Skřivan $\mathrm{ml}$

Kvapil, Antonín (2001): Malý Brehm: Savci. Praha: Levné knihy KMa.

Leach, Marjorie (1992): Guide to the Gods. London: Gale.

Leeming, David Adams (2009): Creation Myths of the World: An Encyclopedia I. Greenwood: ABC-CLIO.

Lévi-Strauss, Claude (2006): Mythologica II.: Od medu k popelu. Praha: Argo.

Lévi-Strauss, Claude (2007): Mythologica III: Původ stolničení. Praha: Argo.

Lévi-Strauss, Claude (2009): Mythologica IV.: Nahý člověk. Praha: Argo.

Lévi-Strauss, Claude (2006): Strukturální antropologie. Praha: Argo.

Luckert, Karl (1979): Coyoteway. Tucson: University of Arizona Press.

Mander, Jerry (2003): V neprítomnosti posvátného: Selhání moderních technologií a zápas indiánských národů o prežití. Brno: Doplněk.

McDermott, Gerald (1999): Coyote: A Trickster Tale from the American Southwest. San Diego: Voyager Paperbacks.

Merton, Robert King (2007): Studie ze sociologické teorie. Praha: Sociologické nakladatelství.

Moore, Christopher (1998): Kojotí stesk. Frýdek-Místek: ALPRESS.

Moses, Daniel David (2007): Město kojotů. In: Kolinská, Klára. Čekání na Kojota: současné drama kanadských Indiánů. Brno: Větrné mlýny, 109-214.

Muller, Karl (1978): Huichol Art and Acculturation. In: Berrin, Kathleen, ed., Art of the Huichol Indians. New York: Harry N. Abrams, 84-100.

Perkins, John (1999): Svět proměn: Šamanské techniky směrúuící ke globální a personální transformaci. Praha: Volvox Globator.
Ramsey, Jarold, ed. (1980): Coyote Was Gong There: Indian Literature of the Oregon Country. Seattle: University of Washington press.

Reid, Catherine (2005): Coyote: Seeking the Hunter in Our Midst. New York: Houghton Mifflin.

Ruíz, Vicki L. - Korrol, Virginia Sánchez (2006): Latinas in the United States: A Historical Encyclopedia I. Bloomington: Indiana University.

Smith, David Lee (1997): Folklore of the Winnebago Tribe. Norman: University of Oklahoma Press.

Snyder, Gary (1995): Neuvěřitelná životaschopnost Kojota. In: Snyder, Gary. Staré cesty: Šest esejí. Praha: Volvox Globator. 47-63.

Thorton, Russell (1987): American Indian Holocaust and Survival: A Population History Since 1492. Norman: University of Oklahoma Press.

Tomas, David (1996): Feedback and Cybernetics: Reimaging the Body in the Age of the Cyborg. In: Burrows, Roger - Featherstone, Mike (eds.). Cy berspace/Cyberbodies/Cyberpunk: Cultures of Technological Embodiment. London: Sage Publications, 21-43.

Topol, Jáchym (2008): Trnová dívka: Příběhy severoamerických Indiánů. Praha: Torst.

Ullrich, Jan F. (2002): Mýty Lakotů aneb Když ještě po zemi chodil Iktómi. Praha: Argo.

Vojtěchovský, Miroslav - Vostrý, Jaroslav (2008): Obraz a př́běh: Scéničnost ve výtvarném a dramatickém umění. Praha: Nakladatelství KANT - Karel Jedlický.

Werness, Hope D. (2003): The Continuum Encyclopedia of Animal Symbolism in World Art. New York: Continuum International Publishing Group.

Zelený, Mnislav (1994): Indiánská encyklopedie: Indiáni tř́ Amerik. Praha: Albatros.

\section{AUTORKA}

Půtová, Barbora (14.11. 1985, Praha), česká kulturoložka a historička umění; doktorandka na Katedře teorie kultury (kulturologie) a Ústavu pro dějiny umění Filozofické fakulty Univerzity Karlovy v Praze. Předmět jejího vědecko-výzkumného zájmu představuje problematika pravěkého umění a proměny paradigmat umění v kontextu dějin evropské kultury. Pozornost věnuje také historické a postmoderní antropologii. Průběžně publikuje studie a články věnované osobnosti a uměleckému dílu belgického maliře a ilustrátora Féliciena Ropse. Výsledkem její vědecké spolupráce s antropologem a kulturologem Václavem Soukupem jsou publikace Evoluce člověka a pravěké uměni (2010) a Pravěké umění: evoluce člověka a kultury (2011). Diplomová práce: Kulturní dimenze symbolì jako replikátorů informací: Mediátory kultury v čase a prostoru (2009); rigorózní práce: Memy jako nástroje replikace umění (2010); názvy připravovaných disertačních prácí: Pravěké umění (2011) a Félicien Rops v kontextu své tvorby a doby (2012).

Kontakt: PhDr. Barbora Půtová, Katedra teorie kultury (kulturologie) Filozofické fakulty Univerzity Karlovy v Praze, Celetná 20, 11000 Praha 1, e-mail: bonthyl@email.cz. 